\title{
KERJASAMA “KEMITRAAN INDONESIA - AUSTRALIA UNTUK KESETARAAN GENDER DAN PEMBERDAYAAN PEREMPUAN" (MAMPU) DALAM MENGATASI PERMASALAHAN PEREMPUAN PEKERJA RUMAHAN DI DAERAH ISTIMEWA YOGYAKARTA
}

\author{
Ezzah Nuranisa \\ Alumni Program Studi Hubungan Internasional Fakultas Ilmu Sosial dan Ilmu Politik \\ Universitas Pembangunan Nasional "Veteran" Yogyakarta
}

\section{Asep Saepudin}

Staf Pengajar Fakultas Ilmu Sosial dan Ilmu Politik Program Studi Hubungan Internasional Universitas Pembangunan Nasional "Veteran" Yogyakarta

e-mail : aasaepudin52@yahoo.co.id

\begin{abstract}
This paper describes the existence and condition of women homeworkers (PPR/Perempuan Pekerja Rumahan) in the Special Region of Yogyakarta (DIY). Based on the data and analysis results show that the conditions of the PPR in the Special Region of Yogyakarta in particular and Indonesia in general have not received their proper rights as workers, as stated in the ILO Convention Number 177 of 1996. This is indicated by the existing laws and regulations in Indonesia, commitments and the support of the regional government has not guaranteed PPR rights. Therefore, through the MAMPU Program, in this case YASANTI strives for rights and protection for $P P R$ is guaranteed social protection and rights as workers, such as other formal or informal workers. The MAMPU program carried out for this purpose is to increase the access of homeworkers to social protection programs and improve the conditions of women homeworkers and eliminate discrimination in the workplace. The program has succeeded in placing PPR as a group of workers who need to get social protection and be treated equally in their rights as workers, like other workers.
\end{abstract}

\begin{abstract}
ABSTRAK
Makalah ini menjelaskan keberadaan dan kondisi pekerja rumahan perempuan (PPR / Perempuan Pekerja Rumahan) di Daerah Istimewa Yogyakarta (DIY). Berdasarkan data dan hasil analisis menunjukkan bahwa kondisi PPR di Daerah Istimewa Yogyakarta khususnya dan Indonesia pada umumnya belum menerima hak yang layak sebagai pekerja, sebagaimana dinyatakan dalam Konvensi ILO No. 177 tahun 1996. Hal ini ditunjukkan oleh hukum dan peraturan yang ada di Indonesia, komitmen dan dukungan pemerintah daerah belum menjamin hak PPR. Oleh karena itu, melalui Program MAMPU, dalam hal ini YASANTI mengupayakan hak dan perlindungan bagi PPR dijamin perlindungan sosial dan hak-hak sebagai pekerja, seperti pekerja formal atau informal lainnya. Program MAMPU yang dilakukan untuk tujuan ini adalah untuk meningkatkan akses pekerja rumahan ke program perlindungan sosial dan meningkatkan kondisi pekerja rumahan perempuan dan menghilangkan diskriminasi di tempat kerja. Program ini telah berhasil menempatkan PPR sebagai kelompok pekerja yang perlu mendapatkan perlindungan sosial dan diperlakukan sama dalam hak-hak mereka sebagai pekerja, seperti pekerja lainnya.
\end{abstract}


Kata Kunci : pekerja rumahan perempuan (PPR / Perempuan Pekerja Rumahan), MAMPU, Yasanti, perlindungan sosial, penghapusan diskriminasi.

\section{PENDAHULUAN}

Hasil Survei Angkatan Kerja Nasional (Sakernas) tahun 2016 oleh Badan Pusat Statistik (BPS) Nasional menyebutkan bahwa jumlah penduduk perempuan yang bekerja berjumlah sekitar 45,5 juta jiwa. Sebagian besar perempuan yang bekerja sebanyak 13,7 juta perempuan bekerja di sektor pertanian, kehutanan, dan perikanan. Hal ini berarti bahwa lebih dari $30 \%$ pekerja wanita masuk di sektor perburuhan, seperti ditunjukan dalam grafik 1.

\section{Grafik. 1}

Jumlah Tenaga Kerja Perempuan Berdasarkan Sektor Utama

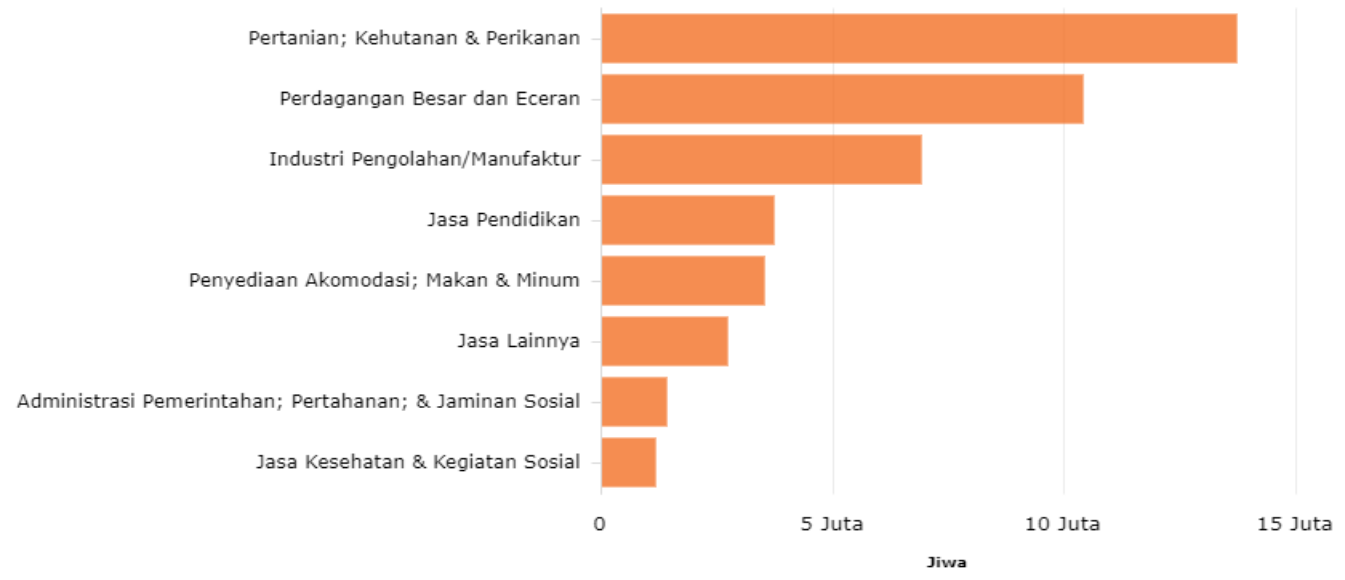

Sumber : Data BPS 2016. Sektor apa yang paling banyak serap pekerja wanita. https://databoks.katadata.co.id/datapublishembed/105974/sektor-apa-yang-palingbanyak-serap-pekerja-wanita diakses pada 20 September 2018

Dari grafik tersebut menunjukan bahwa perempuan yang bekerja di sektor perburuhan sangatlah tinggi, dan pekerja rumahan seringkali disebut dengan pekerja disektor pertanian atau bahkan sering tidak masuk dalam kategori pekerjaan sehingga para pekerja rumahan dianggap bukan seorang pekerja. ${ }^{1}$ Hal ini menunjukan

1 Dinar Dwi Prastya. Pekerja rumahan Indonesia di bawah bayangan patriarki dan kapitalisme global. http://theconversation.com/pekerjarumahan-indonesia-di-bawah-bayanganpatriarki-dan-kapitalisme-global-88963 diakses pada 25 Januari 2019 ketidakberdayaan seorang buruh atau pekerja wanita khusunya pekerja rumahan.

Menurut konvensi ILO, mengenai pekerja rumahan No. 177 tahun 1996, pekerja rumahan didefinisikan sebagai seseorang yang mengerjakan pekerjaan di dalam rumahnya atau di tempat lain pilihannya, selain tempat kerja pemberi kerja. Tujuannya adalah untuk mendapatkan upah yang menghasilkan suatu produk atau jasa sebagaimana yang ditetapkan oleh pemberi kerja, terlepas dari siapa yang menyediakan peralatan, bahan atau input lain yang digunakan. Meski dilindungi Konvensi ILO No. 177 tahun 1996, pekerja rumahan di Indonesia 
memiliki masalah. Pemerintah Indonesia hingga saat ini belum meratifikasi Konvensi tersebut, ${ }^{2}$ sedangkan UU No. 13 tahun 2003 mengenai ketenagakerjaan tidak melindungi pekerja Informal seperti pekerja rumahan, melainkan hanya melindungi pekerja formal. Banyak organisasi Masyarakat saat ini seperti, TURC (Trade Union Rights Center), Bitra Indonesia, Yasanti (Yayasan Annisa Swasti), dan MWPRI (Maju Wanita Pekerja Rumahan Indonesia) menuntut pemerintah untuk mengeluarkan kebijakan yang dapat melindungi pekerja rumahan.

Pekerja rumahan memiliki ciri berbeda dengan pekerja industri rumahan, pekerja rumah tangga dan pekerja pabrik, dimana perbedaannya terdapat dalam cara kerjanya. Pekerja rumah tangga merupakan pekerjaan yang dilakukan seseorang berupa jasa yaitu mengurus urusan rumah tangga milik si pemberi kerja, $^{3}$ sedangkan pekerja rumahan merupakan pekerjaan yang dilakukan seseorang di rumah atau tempat lain untuk memproduksi barang tertentu dengan tujuan diberi upah. Perbedaan antara pekerja rumahan (Homeworkers) dan pekerja industri rumahan (Home Industry) ditunjukan dalam tebel $1{ }^{4}$

2 Jamsos Indonesia, Serikat Pekerja Menolak perbudakan Modern, http://archives.jamsosindonesia.com/cetak/ printout/555. Diakses pada tanggal 10 November 2018.

${ }^{3}$ ILO, Cakupan pekerja rumah tangga di dalam

undang-undang kondisi kerja utama https://www.ilo.org/wcmsp5/groups/public /@asia/@ro-bangkok/@ilo-

jakarta/documents/publication/wcms_1662 64.pdf

4 Eci Ernawati, Pekerja Rumahan dari Perspektif Trade union Rights Centre (TURC),

https://www.academia.edu/7954902/Pekerj a_Rumahan_Home_Workers, Diakses pada 15 Oktober 2018. 
Tabel. 1

Perbedaan Homeworkers dan Home Industry

\begin{tabular}{|c|c|c|c|}
\hline \multirow{2}{*}{\multicolumn{2}{|c|}{ No. Kriteria }} & \multicolumn{2}{|c|}{ Perbedaan } \\
\hline & & Homeworkers & Home industry \\
\hline 1. & $\begin{array}{l}\text { Pemberi } \\
\text { kerja }\end{array}$ & $\begin{array}{l}\text { Ada pemberi kerja (seseorang, } \\
\text { perorangan atau badan hukum). }\end{array}$ & $\begin{array}{l}\text { Tidak ada pemberi kerja } \\
\text { (seseorang, perorangan atau } \\
\text { badan hukum). }\end{array}$ \\
\hline 2. & $\begin{array}{c}\text { Sumber } \\
\text { pekerjaan }\end{array}$ & $\begin{array}{l}\text { Para pekerja ini menerima pekerjaan } \\
\text { dari sub-kontraktor atau perantara dan } \\
\text { dibayar menurut jumlah barang/projek } \\
\text { yang diproduksi. }\end{array}$ & $\begin{array}{l}\text { Pekerja home industry bekerja } \\
\text { atas usaha mandiri. }\end{array}$ \\
\hline 3. & $\begin{array}{l}\text { Status } \\
\text { pekerja }\end{array}$ & $\begin{array}{l}\text { Status pekerja individual, kalaupun } \\
\text { mengajak orang lain dia hanya sebagai } \\
\text { agen/perantara (biasa disebut mocok/ } \\
\text { mbok- mbokan), sedangkan orang lain } \\
\text { tersebut hanya bersifat } \\
\text { membantu/bekerja sama. Tidak ada } \\
\text { status karyawan. }\end{array}$ & $\begin{array}{l}\text { Memungkinkan untuk merekrut } \\
\text { orang lain (dalam jumlah yang } \\
\text { mungkin tidak besar). Dan } \\
\text { orang lain yang direkrut } \\
\text { tersebut bisa berstatus } \\
\text { karyawan. }\end{array}$ \\
\hline 4 & Upah & $\begin{array}{l}\text { Upah didapat langsung dari } \\
\text { perusahaan/pemberi kerja/ perantara si } \\
\text { pemberi kerja di mana dia mengambil } \\
\text { barang untuk diproduksi. Apabila dia } \\
\text { sebagai agen/perantara (biasanya } \\
\text { disebut mocok/mbok - mbokan), Upah } \\
\text { dibagi rata sesuai dengan banyaknya } \\
\text { barang produksi yang dikerjakan. Jika } \\
\text { upah agen lebih besar, biasanya hanya } \\
\text { sekadar potongan untuk transport } \\
\text { tetapi bukan merupakan keuntungan. }\end{array}$ & $\begin{array}{l}\text { Yang memberikan upah adalah } \\
\text { yang memiliki home industry. } \\
\text { Pemilik home industry } \\
\text { mendapatkan keuntungan, } \\
\text { karyawan home industry } \\
\text { memperoleh upah }\end{array}$ \\
\hline 5. & $\begin{array}{c}\text { Kontak } \\
\text { dengan } \\
\text { pasar }\end{array}$ & $\begin{array}{l}\text { Yang kontak langsung dengan pasar } \\
\text { adalah si pemberi kerja. Mereka tidak } \\
\text { memiliki kontak langsung dengan } \\
\text { pasar untuk barang yang mereka } \\
\text { hasilkan. Namun dikembalikan lagi } \\
\text { kepada si pemberi kerja. }\end{array}$ & $\begin{array}{l}\text { Para pekerja ini umumnya } \\
\text { berhubungan langsung dengan } \\
\text { pasar. Mereka menghadapi } \\
\text { persaingan langsung dengan } \\
\text { perusahaan- perusahaan lain. }\end{array}$ \\
\hline 6. & $\begin{array}{l}\text { Hasil } \\
\text { produk }\end{array}$ & $\begin{array}{l}\text { Hasil produksi ditentukan oleh } \\
\text { pemberi kerja. Untuk bahan baku dan } \\
\text { alat-alat terkait lainnya bisa juga } \\
\text { berasal dari pemberi kerja secara } \\
\text { keseluruhan maupun sebagian. }\end{array}$ & $\begin{array}{l}\text { Hasil produksi ditentukan oleh } \\
\text { pekerja home industry itu } \\
\text { sendiri. Para pekerja home } \\
\text { industry mengatur bahan baku } \\
\text { dan alat-alat terkait lainnya } \\
\text { sendiri, dan menanggung } \\
\text { semua biaya infrastruktur } \\
\text { untuk memproduksi barang. }\end{array}$ \\
\hline
\end{tabular}

Sumber: hasil kajian Eci Ernawati, Research Division of TURC (Trade Union Rights Center)

Berdasarkan tabel di atas tidak memiliki hak-hak yang jelas menunjukkan bahwa pekerja rumahan sebagaimana pekerja pada umumnya. 
Mereka tidak memiliki kontrak yang jelas, pemenuhan upah yang tidak menentu, serta jaminan kesehatan dan ketenagakerjaan yang dapat menjamin keselamatan kerja. Hak-hak lain seperti perlindungan hukum, fasilitas kerja yang memadai, waktu pengerjaan, tunjangan hari raya, dan santunan menunjukan bahwa pekerja rumahan tidak mendapatkan hak-hak selayaknya tertuang dalam UU ketenagakerjaan No. 13 tahun 2003.

\section{Dari permasalahan yang dimiliki} pekerja rumahan, terdapat empat permasalahan pokok yaitu: para pekerja rumahan membutuhkan jaminan kesehatan dan keselamatan kerja serta pemenuhan fasilitas kerja, belum ada payung hukum yang berlaku di Indonesia untuk melindungi pekerja rumahan, dibutuhkan serikat pekerja rumahan sebagai akses informasi dan pengetahuan sehingga memunculkan rasa solidaritas dan mengurangi persaingan kerja, perjanjian kontrak bersama bagi pemberi kerja dan penerima kerja meliputi: pembagian upah yang selama ini masih minim, Tunjangan Hari Raya (THR) dan pembagian waktu, istirahat dan cuti.

Permasalahan tersebut juga dialami oleh pekerja rumahan di Yogyakarta. Oleh karenanya dalam rangka untuk memberikan perlindungan dan membela hak-hak pekerja rumahan, khususnya di DIY, Pemerintah Indonesia dan Pemerintah Australia melakukan kerjasama dan membuat program yang disebut MAMPU. ${ }^{5} 1200$ perempuan

\footnotetext{
${ }^{5}$ MAMPU adalah Program "Kemitraan Australia dan Indonesia untuk Pemberdayaan Perempuan". Program MAMPU disepakati pada tanggal $21 \mathrm{Mei}$ 2012 oleh pemerintah Indonesia dan pemerintah Australia dan efektif berjalan sejak tahun 2012 hingga 30 Juni 2016. Program ini dilanjutkan ke Fase II dengan ditandatanganinya Subsidiary Arrangement Program MAMPU
}

pekerja rumahan di Yogyakarta dari 3000 perempuan binaan MAMPU di 7 Provinsi di Indonesia, Yogyakarta memiliki potensi besar dalam program pemberdayaan pekerja layak bagi pekerja rumahan. Kemitraan Indonesia Australia untuk kesetaraan gender dan pemberdayaan perempuan (MAMPU) bekerjasama dengan mitra MAMPU yaitu Yayasan Annisa Swasti (Yasanti) bertujuan untuk mendorong perempuan pekerja rumahan di Yogyakarta untuk maju dan berdaya sehingga kondisi pekerjaan bagi pekerja rumahan dapat dikatakan sebagai pekerjaan yang layak.

Berdasarkan permasalahan tersebut, tulisan ini akan melihat bagaimana pelaksanaan Kerja Sama Kemitraan Indonesia-Australia untuk Kesetaraan Gender dan Pemberdayaan Perempuan (MAMPU) dalam Mengatasi Permasalahan Perempuan Pekerja Rumahan di Yogyakarta.

\section{A. Perempuan Pekerja Rumahan (PPR) di Indonesia}

Pekerja rumahan di Indonesia tersebar dibeberapa wilayah seperti di Medan, Banten, Semarang, Yogyakarta dan Jawa Timur. Beberapa wilayah di Indonesia belum terdeteksi oleh MAMPU, dan tidak ada data yang menunjukan angka pasti berapa pekerja rumahan yang tersebar di Indonesia. Pemetaan pekerja rumahan masih berlangsung di tiap kota dan kabupaten sampai ke daerah pedesaan. Pemetaan ini dilakukan oleh MAMPU karena pekerja rumahan belum terdaftar

Kemitraan Australia dan Indonesia untuk Pemberdayaan Perempuan Fase II antara Imron Bulkin sebagai Sekretaris Kementerian Perencanaan Pembangunan Nasional (PPN) atau Sekretaris Utama Bappenas bersama dengan Fleur Davies sebagai Minister-Counsellor of Governance and Human Development of Australian Embassy di Hotel Double Tree Jakarta. 
sebagai pekerja. $^{6}$ Sebagian pekerja rumahan masih disebut sebagai ibu rumah tangga atau perempuan yang tidak memiliki pekerjaan. Hasil dari pemetaan yang dilakukan oleh MAMPU tersebut dapat dilihat bahwa pekerja rumahan mermiliki karakteristik sebagai berikut ${ }^{7}$ : pekerja miskin yang lemah skill atau memiliki ketrampilan rendah, pekerja rumahan belum terdaftar dalam data statistik sebagai pekerja, sehingga data belum disajikan, pekerja rumahan secara hukum, oleh Undang-Undang Ketengakerjaan, kedudukannya juga belum jelas karena sifat pekerja rumahan masih tidak tampak (Invisible), Sehingga perlindungan hubungan kerja melalui kontrak kerja lisan membuat posisi tawar menjadi lemah, dan pekerja rumahan nyaris luput dari perbincangan ilmuwan, dan belum banyak diangkat ke permukaan sebab jumlahnya tak muncul dalam angka stastistik.

${ }^{6}$ Urip Wiharnato. 2018. Pekerja Rumahan di DIY dan sistem Out sourching. YASANTI

7 Lembar kebijakan; YASANTI, Pentingnya perlindungan dan pengakuan bagi pekerja rumahan DIY, Diajukan ke DPRD pada tanggal 26 November 2018 


\section{Gambar. 1}

Working Area Program MAMPU tahun 2018
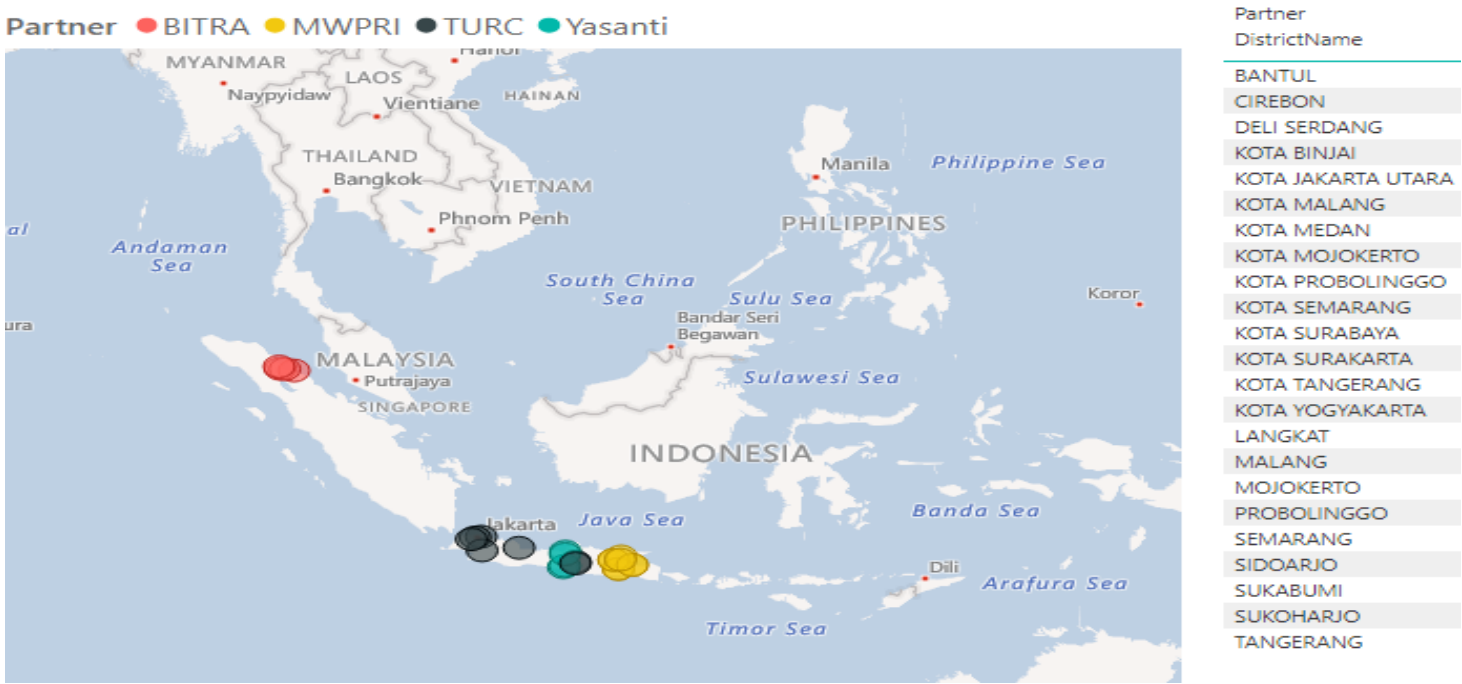

Sumber : Data MAMPU 2018, Perbaikan Kondisi Kerja http://mampu.or.id/tema/perbaikankondisi-kerja/, diakses pada 12 Desember 2018

Gambar di atas menunjukan pemetaan area oleh empat mitra MAMPU yang memiliki tujuan untuk mengatasi permasalahan kondisi kerja perempuan di Indonesia. Mitra MAMPU tersebut adalah Bitra Indonesia berwarna merah yang mengampu pekerja rumahan di Medan, Sumatra Utara, TURC (Trade Union Rignts Center) berwarna hitam yang mengampu pekerja rumahan di Banten dan Jawa Tengah, MWPRI (Maju Wanita Pekerja Rumahan) berwarna kuning yang mengampu pekerja rumahan di Jawa Timur dan Yasanti (Yayasan Annisa Swasti) berwarna biru yang mengampu pekerja rumahan di Yogyakarta. Menurut data MAMPU terdapat 3000 perempuan pekerja dengan 140 kelompok di 158 desa di 23 kabupaten dan 7 provinsi. $^{8}$

Permasalahan utama pekerja rumahan ini adalah kompleksitas alur kerja. Jika pekerjaan pada umumnya adalah pemberi kerja dan pekerja, dalam

${ }^{8}$ Data MAMPU 2018, Tema Perbaikan Kondisi Kerja http://mampu.or.id/tema/perbaikankondisi-kerja/, diakses pada 12 Desember 2018 alur pekerja rumahan memiliki alur kerja yang lebih rumit yakni munculnya istilah Putting out system. Karakteristik Putting out System yaitu: tempat pekerja adalah rumah pekerja, sifat pekerja adalah suka rela, hubungan kerja cenderung melalui perjanjian lisan serta bersifat informal, dan pekerja rumahan tidak mempunyai wewenang menentukan pembeli dan pemasaran produk. ${ }^{9}$ Sistem ini merupakan praktek dalam melakukan pekerjaan subkontrak dari perusahaan atau dari pengusaha lain. Tidak semua perempuan pekerja rumahan memiliki perintah kerja secara langsung dengan pengusaha, sebagian dari mereka mendapat perintah melalui perantara. Keberadaan perantara ini menjadikan posisi pekerja rumahan semakin rumit dalam alur kerja, mereka direkrut secara subjektif oleh perantara dan sebagian pekerja rumahan memberikan separuh pekerjaannya kepada orang lain, sehingga ada pula pekerja rumahan yang merangkap menjadi perantara.

9 Urip Wiharnato, Pekerja Rumahan di DIY dan sistem Out sourching, Kumpulan Dokumen Hasil Seminar dengan Tema "Perburuhan" YASANTI 2016 
Alur kerja yang rumit ini, seperti dalam gambar 1, mengakibatkan pekerja rumahan sulit untuk diakui keberadaannya sebagai pekerja dan tidak mendapatkan hak-haknya sesuai regulasi UndangUndang Ketenagakerjaan No. 13 tahun 2003. Menurut data Yasanti pola distribusi pekerjaan ini memiliki beberapa variasi yaitu: perusahaan induk mempekerjakan langsung pekerja rumahan, perusahaan induk menjalin kontrak kerja dengan perantara yang mempekerjakan pekerja rumahan, serta perusahaan induk menjalin kontrak kerja dengan perusahaan supplier yang mempekerjakan pekerja rumahan baik secara langsung maupun melalui perantara. ${ }^{10}$

10 Lembar kebijakan; YASANTI, Pentingnya perlindungan dan pengakuan bagi pekerja rumahan DIY, Diajukan ke DPRD pada tanggal 26 November 2018 
Gambar. 2

Alur Rantai Produksi dan Keberadaan Pekerja Rumahan di Industri

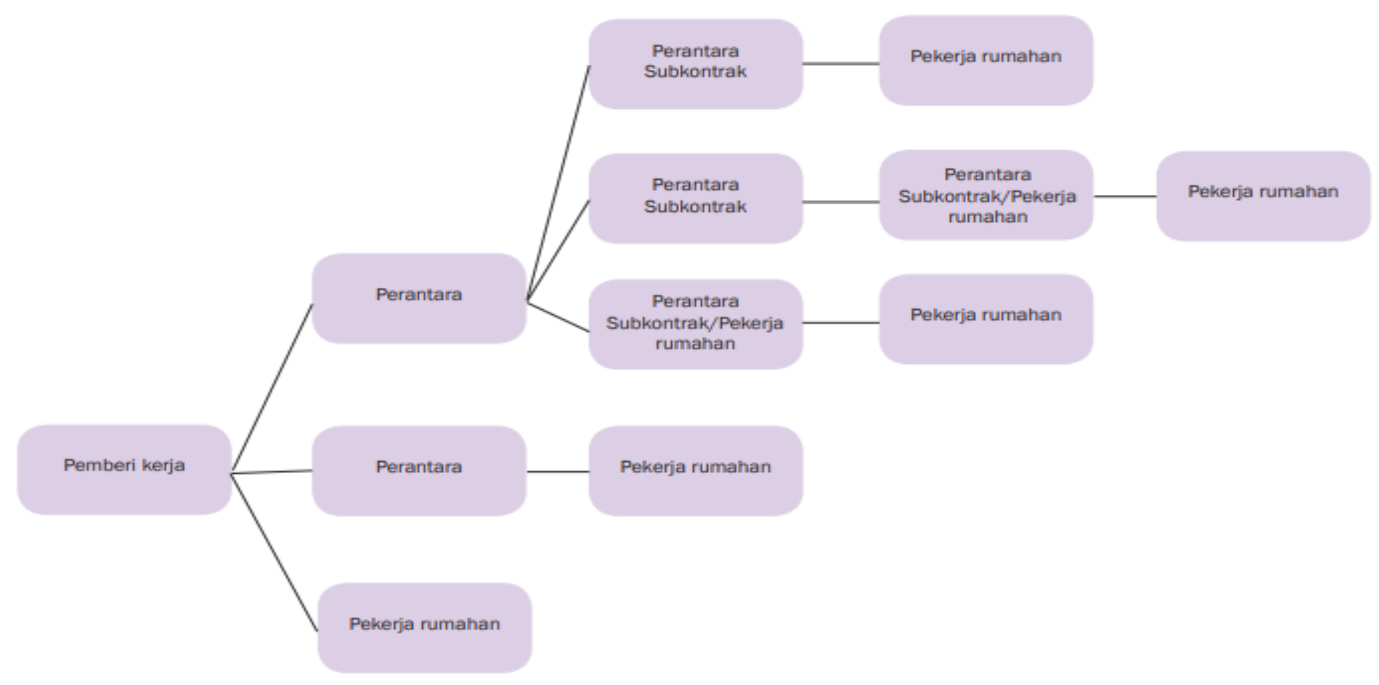

Sumber : Asosiasi Pengusaha Indonesia (APINDO), 2013, Panduan Praktik yang Baik untuk Mempekerjakan Pekerja Rumahan bagi Pengusaha, Jakarta, ILO, Hal. 4

\section{B. PPR di DIY}

Yogyakarta merupakan salah satu kota yang terkenal dengan pasar seni, kerajinan, kuliner khas, industri pakaian dan berbagai macam kerajinan cindera mata dan barang-barang unik lainnya, karya seni dari Yogyakarta ini telah diakui dan telah tersebar di pelosok Indonesia. Banyak wisatawan domestik maupun mancanegara yang tertarik untuk datang ke Yogyakarta untuk membeli dan mempelajari karya seni tersebut dan membuat industri kerajinan semakin memiliki banyak peminat. Para perajin, dan pekerja ini ada yang membuat kerajinan di satu tempat yang sama, namun ada juga yang membawa bahan kerajinannya ke rumah. Perajin yang membawa pekerjaan ke rumahnya bisa disebut dengan pekerja rumahan. Para pekerja rumahan ini biasanya tidak memiliki kekuatan secara ekonomi maupun sosial, tidak memiliki kemampuan untuk membeli bahan secara utuh, sehingga para perajin ataupun pekerja rumahan diupah sesuai jumlah barang yang mereka produksi dan tidak bisa memasarkan barang produksi mereka sendiri. Beberapa sektor pekerjaan yang dikerjakan oleh perempuan pekerja rumahan di DIY ditunjukan dalam tabel 2.

Tabel. 2

Perempuan Pekerja Rumahan (PPR) di Provinsi DIY

\begin{tabular}{|c|c|c|c|c|}
\hline Daerah & Jumlah & $\begin{array}{c}\text { Rata-rata } \\
\text { Tingkat } \\
\text { pendidikan }\end{array}$ & Rata-rata Sektor pekerjaan & $\mathbf{K 3}$ \\
\hline Kota Yogyakarta & 184 & SMP-SMA & Pakaian jadi, kulit, makanan & Tidak ada \\
\hline Kabupaten Sleman & 200 & SMP-SMA & $\begin{array}{l}\text { Pakaian jadi/tas, makanan } \\
\text { minuman, dan tekstil }\end{array}$ & Tidak ada \\
\hline Kabupaten Bantul & 859 & SMP-SMA & $\begin{array}{c}\text { Makanan, } \\
\text { kayu/anyam/bambu/rotan }\end{array}$ & Tidak ada \\
\hline
\end{tabular}


Sumber : Hasil Penelitian YASANTI tahun 2016-2018

Berdasarkan tabel di atas menunjukan bahwa banyak pekerja rumahan berasal dari Kabupaten Bantul. Hal ini dikarenakan banyak pusat kerajinan yang berasal dari Kabupaten Bantul dengan proporsi kerja berasal dari lulusan SMP dan SMA. Hal ini menunjukan bahwa pekerja rumahan banyak diminati oleh pekerja dengan sertifikasi pendidikan di bawah SMA. Dari tabel tersebut, dapat dilihat bahwa ketrampilan yang mereka miliki tidak dapat mendorong mereka untuk melakukan usaha secara mandiri. Selain itu, tidak adanya perlindungan K3 / Kesehatan Keselamatan Kerja membuat pekerja rumahan di Yogyakarta tidak terlindungi baik dari pemberi kerja mauun dari pemerintah Yogayakarta.

Para pekerja rumahan di Yogyakarta ini melakukan pekerjaan di rumah tempat tinggalnya dengan batas waktu kerja yang tidak jelas. Pekerjaan dengan menggunakan lingkungan rumah tentu merugikan pekerja rumahan tersebut, seperti megurangi ruang untuk tinggal karena digunakan untuk meletakan alat dan bahan. Jika menggunakan alat dan bahan yang berbahaya dapat melukai si pekerja dan keluarganya. Selain itu pekerjaan yang dilakukan di rumah rentan mengalami eksploitasi pekerja anak karena anak memiliki kecenderungan untuk diberi perintah atas dasar sukarela membantu pekerjaan di rumah. ${ }^{11}$ Karena tidak adanya hubungan yang jelas inilah sulit bagi pekerja dan pemberi kerja melakukan kontrak kerja sehingga baik pemberi kerja ataupun pekerja tidak dapat melakukan hubungan kerja yang sesuai dengan regulasi Undang-Undang Ketengakerjaan No. 13 tahun 2003 secara baik dan benar.

11 TURC, Siapa Pekerja Rumahan?, https://www.turc.or.id/siapa-pekerjarumahan/, Diakses pada 13 Desember 2018 
Tabel. 3

Upah Minimum Regional Yogyakarta Tahun 2018

\begin{tabular}{ccc}
\hline No. & Kabupaten/Kota & Upah Minimum Kabupaten/Kota \\
\hline 1. & Kota Yogyakarta & Rp. $1.709 .150,00$ \\
2. & Kabupaten Sleman & Rp. $1.574 .550,00$ \\
3. & Kabupaten Bantul & Rp. $1.527 .150,00$ \\
4. & Kabupaten Gunung Kidul & Rp. $1.493 .250,00$ \\
5. & Kabupaten Kulonprogo & Rp. $1.454 .200,00$ \\
\hline
\end{tabular}

Sumber : Keputusan Gubernur Daerah Istimewa Yogyakarta No. 223 Tahun 2017 tentang penetapan Upah Minimum Kabupaten/Kota

Tabel. 4

Identifikasi Jenis Pekerjaan bagi Pekerja Rumahan di Tiga Kabupaten / Kota Provinsi Daerah Istimewa Yogyakarta (orang)

\begin{tabular}{|c|c|c|c|c|c|c|c|c|c|c|c|c|c|c|}
\hline \multirow{3}{*}{ Daerah } & \multicolumn{4}{|c|}{ Sektor Industri } & \multicolumn{8}{|c|}{ Upah (Rp)/ sektor Industri } & \multicolumn{2}{|c|}{$\begin{array}{l}\text { Tunjang } \\
\text { an PPR }\end{array}$} \\
\hline & \multirow{2}{*}{$\begin{array}{l}\text { స్ } \\
\text { 䒕 } \\
\text { 䒕 }\end{array}$} & \multirow{2}{*}{ 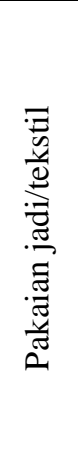 } & \multirow{2}{*}{ 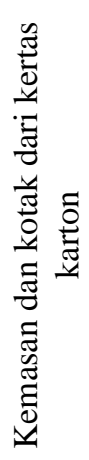 } & \multirow{2}{*}{ 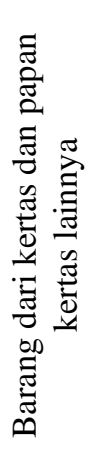 } & \multicolumn{2}{|c|}{ 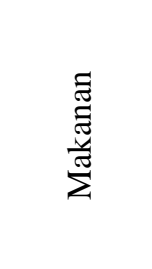 } & \multicolumn{2}{|c|}{ 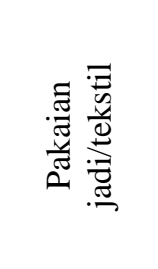 } & \multicolumn{2}{|c|}{ 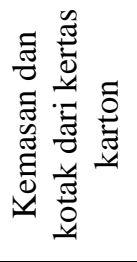 } & \multicolumn{2}{|c|}{ 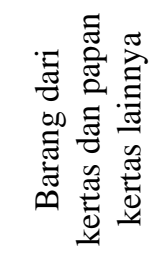 } & \multirow[t]{2}{*}{$\approx$} & \multirow[t]{2}{*}{ 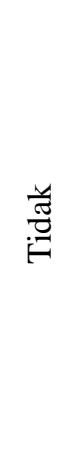 } \\
\hline & & & & & $\begin{array}{l} \pm \\
\vec{v}\end{array}$ & $\stackrel{ \pm}{\pi}$ & $\stackrel{\vec{v}}{\vec{v}}$ & $\stackrel{2}{\pi}$ & $\begin{array}{l} \pm \\
\vec{v}\end{array}$ & $\stackrel{ \pm}{\pi}$ & $\begin{array}{l}\vec{D} \\
\vec{v}\end{array}$ & \pm & & \\
\hline $\begin{array}{c}\text { Kota } \\
\text { Yogyakarta }\end{array}$ & 56 & 123 & 29 & 59 & 56 & 0 & 115 & 0 & 29 & 0 & 48 & 1 & 1 & 159 \\
\hline Kab. Sleman & 33 & 57 & 22 & 91 & 33 & 0 & 57 & 0 & 22 & 0 & 91 & 0 & 1 & 204 \\
\hline Kab. Bantul & 174 & 193 & 18 & 615 & 197 & 0 & 170 & 0 & 18 & 0 & 615 & 0 & 1 & 95 \\
\hline Jumlah & 263 & 373 & 69 & 755 & 286 & $\mathbf{0}$ & 342 & $\mathbf{0}$ & 69 & 0 & 754 & 1 & 3 & 458 \\
\hline
\end{tabular}

Sumber: Hasil Penelitian Yasanti Tahun 2016-2018

Perempuan pekerja rumahan dipaksa bekerja tanpa batas waktu dan mengerjakan pekerjaan rumahan selama 24 jam. Selain pekerjaan dengan durasi waktu yang tidak jelas, pekerjaan ini juga rentan memanfaatkan anak dalam menyelesaikan tugas pekerjaannya dan juga anggota rumah tangga lain yang tidak dibayar untuk membantu menyelesaikan pekerjaan sehingga perlu adanya pengawasan, bantuan pemerintah dan hukum dalam memantau sistem pekerja rumahan, agar perempuan pekerja rumahan berdaya dan mengalami peningkatan kesejahteraan.

C. Program MAMPU di Indonesia

Program MAMPU merupakan program dukungan dalam pencapaian Rencana Pembangunan Jangka Menengah Nasional (RPJMN) tahun 2015 hingga tahun 2019 dan juga merupakan program 
yang bertujuan untuk Tujuan Pembangunan Berkelanjutan (TPB) atau Sustainable Development Goals (SDG's) tujuan 5 yang disahkan Perserikatan Bangsa-Bangsa (PBB) dengan prinsip dasar utama: Kesetaraan Gender, Hak-hak perempuan sebagai hak asasi manusia, Pemberdayaan Perempuan, Ketimpangan kekuasaan yang tidak setara. Dari ke empat prinsip tersebut munculah sembilan target yang bertujuan untuk mengubah ketidaksetaraan hubungan kekuasaan antara perempuan dan laki-laki, yang dapat menghambat kemajuan perempuan secara struktural dan budaya. ${ }^{12}$

Untuk mencapai prinsip dari Tujuan Pembangunan Berkelanjutan tersebut program MAMPU mengembangkan penggabungan kapasitas perempuan dan memberdayakan para perempuan tersebut untuk mempengaruhi pengambilan keputusan ditingkat desa hingga tingkat nasional. Tujuan dari Program MAMPU ini adalah mengakhiri kemiskinan, pemenuhan nutrisi dan gizi bagi perempuan, mengakses pendidikan bagi perempuan, memperbaiki kondisi kerja dari diskriminasi pekerjaan (Kerja layak), menghapus ketimpangan sosial terhadap perempuan, dan memperbaiki kondisi masyarakat dan instituisi secara inklusif untuk menciptakan keadilan bagi semua termasuk di dalamnya perempuan dan anak-anak. $^{13}$ Untuk mencapai tujuan program MAMPU dalam memperdayakan perempuan terdapat kerangka pemberdayaan yang menjadi acuan program MAMPU dalam membantu perempuan meningkatkan aset akses terbatas yang mereka miliki menjadi kekuatan bagi perempuan dalam

12 Dewi Komalasari, 2017, Tujuan Pembangunan Berkelanjutan (TPB), Semai Edisi 3, Hal. 7-8

${ }^{13}$ Buletin MAMPU tahun 2018, Kerangka Kerja Kesetaraan Gender dan Pemberdayaan perempuan, MAMPU, Agustus 2018, hal. 4 memberdayakan diri, seperti ditunjukan dalam tabel di bawah ini. 
Tabel. 5

Kerangka Pemberdayaan Perempuan

\begin{tabular}{lll}
\hline \multicolumn{1}{c}{ Aset Akses } & & \multicolumn{1}{c}{ Kerangka } \\
\hline Aset & - Kesehatan (akses kepada layanan dan informasi kesehatan \\
Manusia & - Pendidikan, literasi, numerasi \\
(kekuatan di & - Literasi keuangan \\
dalam) & - Pengetahuan tentang Hak Asasi Manusia (HAM) dan hak hukum \\
& - Ketrampilan yang berguna untuk mencari kerja \\
Aset & - Harga diri dan rasa percaya diri \\
Keuangan & - Uang tunai, pendapatan, dan tabungan \\
dan Sumber & - Kupon / Voucher \\
daya & - Peralatan / input (benih, pupuk, bahan mentah \\
(kendali) & - Ternak dan persediaan barang \\
& - Usaha dan informasi pasar \\
Aset & - Partisipasi dalam keputusan ekonomi di keluarga \\
Kapasitas & - Partisipasi dalam pengambilan keputusan di masyarakat \\
(Kemampuan & - Mengakses layanan dan perlindungan sosial \\
untuk) & - Berhubungan dengan pasar, termasuk dengan agen penempatan \\
& - pekerja migran dan pemberi kerja \\
Aset Sosial & - Menan, jaringan sosial \\
(Kemampuan & - Keanggotaan kelompok \\
dengan) & - Hubungan dengan pemerintah kabupaten dan penyedia layanan \\
& - Hubungan dengan masyarakat sipil dan kelompok lainnya \\
Aset & - Kartu Identitas \\
Pendukung & Kerangka Hukum, kebijakan, serta hak transportasi dan \\
& infrastruktur yang menghemat waktu \\
\hline Sumberawatan anak
\end{tabular}

Sumber : Buletin MAMPU tahun 2018, Kerangka Kerja Kesetaraan Gender dan Pemberdayaan perempuan, MAMPU, Agustus 2018

\section{Program MAMPU di DIY}

Program MAMPU di DIY terdiri dari 2 program utama yaitu: (1) peningkatkan akses pekerja rumahan pada program perlindungan sosial dan (2) memperbaiki kondisi perempuan pekerja rumahan dan menghapuskan diskriminasi di tempat kerja.

\section{Peningkatkan akses pekerja rumahan pada program perlindungan sosial}

Di dalam Undang- Undang No. 13 Tahun 2003 Pasal 99 Ayat 1 mengatakan bahwa setiap pekerja atau buruh dan keluarganya berhak untuk memperoleh jaminan sosial tenaga kerja. Oleh karenanya program MAMPU mendorong pemerintah khususnya bagi pemerintah dinas ketenagakerjaan di tingkat Nasional, Provinsi dan Kabupaten/Kota yang merupakan ujung tombak pelaksanaan kebijakan mengenai perlindungan pekerja rumahan perlu mengembangkan kelembagaan untuk melakukan koordinasi pendataan, pengurusan dan penerbitan perizinan, dan penyerahan dokumen 
perencanaan dan pelaporan serta melakukan evaluasi secara berkala terkait dengan eksistensi pekerja rumahan di wilayahnya. ${ }^{14}$ Untuk mendukung program advokasi pekerja rumahan, program MAMPU telah melakukan beberapa kegiatan yaitu: (1) Audiensi dengan pemerintah, (2) Pendataan jumlah perempuan pekerja rumahan, (3) Melakukan kampanye melalui media, akademisi dan jaringan NGO yang mendukung pengadvokasian pekerja rumahan.

Audiensi dengan pemerintah DIY yang telah dilakukan Yasanti dalah: pertama melakukan audiensi pemerintah Daerah Istimewa Yogyakarta yang kemudian menghasilkan draf Peraturan Gubernur Bidang Ketenagakerjaan (Pekerja Rumahan/Buruh Rumahan) di DIY yang dilaksanakan oleh Bagian Analisa Kebijakan Kesejahteraan Rakyat Biro Administrasi Kesra dan Kemasyarakatan Sekda DIY tahun Anggaran 2017. ${ }^{15}$ Kedua, melakukan audiensi dengan Bupati Bantul melalui dialog bersama Perempuan Pekerja Rumahan (PPR) Yogyakarta, yang kemudian menghasilkan pegakuan tertulis dari Disnakestrans Bantul untuk lima organisasi PPR di Bantul sebagai serikat pekerja. ${ }^{16}$ Selain itu, adanya program pelatihan dan pemeriksaan kesehataan bagi PPR yang dianggarkan oleh Disnakestrans Bantul, dan juga adanya dukungan dari

\footnotetext{
${ }^{14}$ Lembar Kebijakan Yasanti, Pentingnya perlindungan dan pengakuan bagi pekerja rumahan DIY, diajukan ke DPRD DIY pada tanggal 26 November 2018

${ }^{15}$ Analisa kebijakan Kesra dan

Kemasyarakatan Sekda DIY, pekerja rumahan tahun 2017, peraturan Gubernur 2017

${ }^{16}$ Laporan Yasanti Catur Wulan Program MAMPU Oktober - Desember 2016, Tanggal Proyek 1 Juni 2016
}

Bupati Bantul dengan menyediakan fasilitas seperti tempat pembentukan federasi SPPR di Joglo Parasamia Kabupaten Bantul oleh Pemerintah Kabupaten Bantul merupakan hasil audiensi tersebut.

Ketiga, Mitra MAMPU juga telah melakukan audiensi kepada Pemerintah Desa Wonolelo, Bawuran, Segoroyoso, Wukirsari, Bangunjiwo, Kabupaten Bantul dengan hasil audiensi, di antaranya: (1) penerbitan dan serah terima Surat Keputusan No. 25 tahun 2017 oleh Kepala Desa Bangunjiwo tentang pembentukan pengurus dan pencatatan SPPR Kasih Bunda Desa Bangunjiwo Kecamatan Kasihan Kabupaten Bantul pada tanggal 5 Desember 2017, (2) Kepala Desa Bangunjiwo mendukung mengeluarkan surat permohonan kepada Bupati Bantul dan kepala Disnakertrans DIY untuk mengajukan proposal pelatihan menjahit dan pengajuan sepuluh mesin jahit untuk SPPR Kasih Bunda, (3) penerbitan dan serah terima Surat Keputusan No. 23 tahun 2017 oleh Kepala Desa Bawuran tentang pembentukan pengurus dan pencatatan SPPR Bunda Mandiri Desa Bawuran Kecamatan Pleret Kabupaten Bantul pada tanggal 30 November 2017, (4) Lurah Pemerintah Tahunan Kecamatan Umbulharjo, Lurah Pemerintah Prenggan Kecamatan Kotagede, Lurah Pemerintah Cokrodiningratan Kecamatan Jetis, Lurah Pemerintah Tegal Panggung Kecamatan Danurejan, dan Lurah pemerintah Notoprajan Kecamatan Ngabean telah memfasilitasi ruang rapat dikelurahan untuk kegiatan Pemenbentukan dan peresmian SPPR. Keempat, Mitra MAMPU melakukan audiensi terhadap Pemerintah Kelurahan Prenggan Kecamatan Kotagede, Kota Yogyakarta memberikan surat rekomendasi untuk mencatat SPPR Mutiara Bunda ke Disnakertrans Kota Yogyakarta pada tanggal 1 Oktober 2018 dan audiensi mitra Yasanti terhadap Pemerintah Kelurahan Notoprajan Kecamatan Ngampilan Kota 
Yogyakarta telah memasukan data 17 PPR anggota SPPR Harapan Bunda Lurah Notoprarajan sebagai calon peserta pelatihan di program pemerintah kelurahan Notoprajan tahun 2019.

Mitra MAMPU juga telah melakukan pendataan secara mandiri di tiga Kabupaten/Kota di DIY. Pendataan ini perlu dilakukan agar pemerintah dan masyarakat mengetahui berapa besaran jumlah pekerja rumahan di Indonesia khususnya di Yogyakarta. Pendataan jumlah pekerja rumahan berguna untuk pengajuan regulasi Undang-Undang untuk perlindungan PPR. ${ }^{17}$ Dengan adanya pendataan maka akan memudahkan pemerintah dalam mengeluarkan undangundang yang disesuaikan untuk pekerja rumahan di Yogyakarta.

Karena belum ada badan statistik maupun pemerintah dan akademisi yang melakukan pendataan secara langsung mengenai jumlah pekerja rumahan yang berada di Yogyakarta, MAMPU bersama dengan Mitra Yasanti melakukan audit data PPR di tiga kabupaten/kota di DIY. Hasil dari pendataan yang dilakukan oleh mitra Yasanti tersebut adalah terkumpulnya data PPR sebanyak 1.251 orang PPR, terdiri dari 200 orang PPR dari Kabupaten Sleman, 867 orang PPR dari Kabupaten Bantul, dan ada 184 orang PPR dari Kota Yogyakarta. ${ }^{18}$ Dokumen data menunjukan 78 orang anggota SPPR Kreatif Bunda di Desa Wonolelo, 26 orang anggota SPPR Bunda Mandiri di Desa Bawuran, 26 orang anggota SPPR Bunda Berkarya di Desa Segoroyoso, 28 orang anggota SPPR Ngudi Makmur di Desa

\footnotetext{
${ }^{17}$ Mendorong Perda Perempuan Pekerja rumahan di Yogyakarta.

https://spn.or.id/mendorong-perdaperempuan-pekerja-rumahan-diyogyakarta/ diakses pada 15 Desember 2018

${ }^{18}$ Laporan Yasanti Catur Wulan Program MAMPU Oktober - Desember 2016, Tanggal Proyek 1 Juni 2016
}

Wukirsari, dan 24 orang anggota SPPR Kasih Bunda di Desa Bangunjiwo.

Untuk memperkuat upaya advokasi Undang-Undang bagi Pekerja rumahan, kampanye melalui Media, akademisi dan jaringan NGO yang Mendukung Pengadvokasian Pekerja Rumahan juga dilakukan. Beberapa kegiatan kampaye yaitu: (1) membuat berbagai alat kampaye seperti: 150 alat kampanye berupa kaus yang bertuliskan pengakuan dan perlindungan terhadap pekerja rumahan yang diterima oleh tim kerja Yasanti, anggota SPPR Kreatif Bunda DIY, jaringan pendataan PPR Daerah Istimewa Yogyakarta dan Jawa tengah, Disnasketrans DIY, dan Kepala desa dari enam desa di Kabupaten Bantul; (2) melakukan unjuk rasa pada "may day" atau hari buruh pada tanggal 1 Mei 2018 di Malioboro $^{19}$; (3) Kampanye publik 'lindungi pekerja rumahan' pada tanggal 19 September 2018 di Green House Boutique Hotel bersama Kantor Berita Radio $(\mathrm{KBR})^{20}$ yang disiarkan secara nasional dengan narasumber Amin Muftiyanah, sebagai Direktur Yasanti, Sriyati sebagai sekertaris Disnakestrans DIY dan Warisah sebagai perwakilan SPPR.

Di dalam Undang-Undang Ketenagakerjaan No. 13 tahun 2003, UU Jaminan Sosial No. 3 tahun 1992, UU Jaminan Sosial Nasional No. 40 tahun 2004, Peraturan Pemerintah mengenai Program Jaminan Sosial Tenaga Kerja No.14 tahun 1993 dan Peraturan

\footnotetext{
${ }^{19}$ I Ketut Sawitra Mustika, Ini Derita Pekerja Rumahan di Bantul, https://jogjapolitan.harianjogja.com/read/ 2018/05/02/510/913665/ini-deritapekerja-rumahan-di-bantul diakses pada 22 Oktober 2018

${ }^{20}$ Agus Sigit, KBR Suarakan

Perlindungan Pekerja Rumahan, https://krjogja.com/web/news/read/77976/
} KBR_Suarakan_Perlindungan_Pekerja_Ru mahan, Diakses pada 22 Oktober 2018 
Pemerintah

PER-24/MEN/VI/2006 menyebutkan bahwa pekerja berhak mendapatkan jaminan sosial terlepas dari kontrak. Pemberi kerja diwajibkan mendaftarkan dan berkontribusi kepada jaminan sosial ketenagakerjaan (Jamsostek) atau dana jaminan sosial lain bagi pekerja, baik pekerja formal maupun informal. $^{21}$ Hal ini juga berlaku bagi pekerja rumahan yang bekerja secara tetap, sementara, musiman, dan harian. Pekerja rumahan berhak mendapatkan layanan kesehatan berupa jaminan sosial seperti Badan Penyelenggara Jaminan Sosial (BPJS) Kesehatan, BPJS Ketenagakerjaan, atau Kartu Indonesia Sehat. Dalam catatan BPJS Kesehatan pada akhir tahun 2014 menunjukkan bahwa sekitar $44 \%$ pekerja sektor informal menunggak membayar iuran sekitar Rp. 400-an miliar. ${ }^{22}$ Hal ini menunjukan bahwa adanya ketidaksejahteraan di sektor pekerja infromal dan MAMPU mendukung pekerja informal dalam akses jaminan sosial yang kemudian bermitra dengan BPJS kesehatan dan ketenagakerjaan Indonesia.

Untuk sektor pekerja informal di BPJS Ketenagakerjaan masuk ke dalam Kategori Bukan Penerima Upah (BPU). BPU merupakan orang yang memiliki pekerjaan atau usaha ekonomi secara mandiri untuk memperoleh penghasilan dari kegiatan atau usahanya tersebut. Di dalam sosialisasi BPJS Ketenagakerjaan

\footnotetext{
${ }^{21}$ UU Jaminan Sosial No. 3 tahun 1992, pasal 3, 17-19 dan 22, Dikutip dari Asosiasi Pengusaha Indonesia (APINDO), 2013, Panduan Praktik yang Baik untuk Mempekerjakan Pekerja Rumahan bagi Pengusaha, Jakarta, ILO, Hal. 9

${ }^{22}$ Zuardin, 2016, Opini - petakan segera pekerja sektor informal, http://www.jamsosindonesia.com/opini/pet akan_segera_pekerja_sektor_informal. Diakses pada 6 Januari 2019
}

untuk BPU diharapkan dapat memberikan manfaat khusus seperti ${ }^{23}$ :

a) Jaminan Kecelakaan Kerja (JKK), untuk JKK terdiri dari biaya pengangkutan tenaga kerja yang mengalami kecelakaan kerja, biaya perawatan medis dan rehabilitasi, penggantian upah sementara tidak mampu bekerja, santunan cacat sebagian, santunan cacat total tetap, santunan kematian, biaya pemakaman, santunan berkala bagi yang meninggal dunia dan cacat total tetap. Untuk fasilitas yang didapatkan bagi kategori BPU jika dirawat di rumah sakit adalah fasilitas kelas satu dengan pertanggungan pengobatan hingga 20 Juta Rupiah.

b) Jaminan Kematian (JK), khusus untuk Jaminan Kematian meliputi biaya pemakaman dan santunan berkala dan penuh yang akan dibayarkan ke ahli waris.

c) Jaminan Hari Tua (JHT), untuk JHT merupakan keseluruhan iuran yang telah disetor, manfaat dari JHT ialah pekerja informal bisa mendapatkan uang pensiun.

Besar setoran iuran bagi pekerja informal khususnya pekerja rumahan ialah Rp. 16.800,-/bulan. Untuk meningkatkan akses perlindungan sosial bagi PPR, MAMPU melakukan beberapa hal yaitu : (1) melakukan pendataan pekerja rumahan yang memiliki dan tidak memiliki akses kesehatan, (2) melakukan sosialisasi BPJS Ketenagakerjaan, (3) melakukan pendaftaran pekerja rumahan menjadi pekerja informal.

Mitra Yasanti melakukan pendataan terhadap pekerja rumahan di Kota Yogyakarta, Kabupaten Sleman dan Kabupaten Bantul mengenai kepemilikan

${ }^{23}$ Kenapa Sektor informal perlu
perlindungan BPJS Ketenagakerjaan?,
https://jurnal.pasarpolis.com/2018/01/15/p
erlindungan-bpjs-ketenagakerjaan-sektor-
informal/,Diakses pada 15 Januari 2019 
jaminan kesehatan. Pedataan ini penting dilakukan bagi pekerja rumahan agar mengetahui bagaimana akses jaminan kesehatan bagi pekerja rumahan, apakah mereka bekerja dengan jaminan sosial atau tidak, dan apakah pekerja rumahan mendapat jaminan sosial secara mandiri atau diberikan dari pemerintah atau dari pemberi kerja. Hasil dari pendataan PPR tersebut MAMPU mendapatkan data sebagai berikut: dari 184 PPR Kota Yogyakarta terdapat 87 PPR merupakan pemilik jaminan kesehatan sisanya tidak memiliki jaminan kesehatan; dari 200 PPR di Kabupaten Sleman 120 PPR merupakan pemilik jaminan kesehatan sisanya tidak memiliki jaminan kesehatan; dan dari 867 PPR di Kabupaten Bantul 355 PPR merupakan pemilik jaminan kesehatan sisanya tidak memiliki jaminan kesehatan sosial $^{24}$. Kepemilikan jaminan kesehatan ini rata-rata merupakan pemilik jaminan kesehatan yang dibayarkan secara mandiri atau oleh suaminya tapi bukan dari pemerintah atau pemberi kerja. Dengan kondisi seperti ini, MAMPU telah melakukan sosialisasi mengenai pentingnya jaminan social bagi pekerja rumahan di Yogyakarta. ${ }^{25}$

Selain itu, MAMPU juga melakukan Sosialisasi BPJS Ketenagakerjaan yang bekerjasama dengan BPJS Ketenagakerjaan Daerah. Sosialisasi ini pada awalnya dilakukan di dua desa, yaitu pada tanggal 23 November 2017 melakukan sosialisasi untuk 27 anggota SPPR Ngudi Makmur dan 23 UMKM dari desa Wukirsari yang bertempat di Balai

${ }^{24}$ Analisis data tabel Yasanti di tiga

Kabupaten/ Kota Daerah Istimewa

Yogyakarta tahun 2016-2018.

${ }^{25}$ Kornelis Kema Ama, Pekerja Rumahan dan Buruh Butuh Layanan Kesehatan dari Pemerintah.

https://kompas.id/baca/nusantara/2018/12/ 05/pekerja-rumahan-dan-buruh-butuhlayanan-kesehatan-pemerintah/ diakses pada 6 Desember 2018 desa Wukirsari dan pada tanggal 20 desember 2017 di balai desa Bawuran yang di ikuti oleh 26 anggota SPPR Bunda Mandiri, Dukuh dari sanan, dan 3 UMKM dari Bawuran, yang kemudian sosialisasi ini disusul oleh desa-desa lainnya. ${ }^{26}$ Tujuan dari sosialisasi tersebut agar pekerja rumahan menyadari pentingnya jaminan ketenagakerjaan untuk melindungi mereka dari risiko kecelakaan kerja.

Dalam Program MAMPU juga telah dilakukan pendaftaran Pekerja Rumahan Sebagai Pekerja Informal. Pekerja rumahan selama ini tidak diakui sebagai pekerja. Sebagian orang menganggap pekerja rumahan merupakan ibu rumah tangga biasa, sedangkan dalam UU Ketenagakerjaan No. 13 tahun 2003 pekerja rumahan telah memenuhi syarat sebagai pekerja. Oleh karenaya perlu adanya pendaftaran pekerja rumahan sebagai pekerja informal sehingga tidak adanya perbedaan pendapat mengenai pekerja rumahan, pekerja rumah tangga dan pekerja industri rumahan. Hasil mitra MAMPU dalam audiensi dengan BPJS Ketenagakerjaan Daerah Istimewa Yogyakarta sangat membantu bagi pekerja rumahan dalam memasukan pekerja rumahan yang berada di Yogyakarta dalam kategori pekerja informal atau pekerja non upah. $^{27}$ Untuk sektor pekerja informal seperti pekerja rumahan di BPJS Ketenagakerjaan masuk ke dalam Kategori Bukan Penerima Upah (BPU), dengan masuk kedalam kategori tersebut, maka pekerja rumahan berhak atas layanan kesehatan selama 24 jam masa kerja selama kecelakaan yang terjadi akibat pekerjaan. Hasil dari dukungan mitra MAMPU dalam mendaftarkan anggota SPPR ke dalam BPJS Ketenagakerjaan, BPJS ketenagakerjaan memberikan subsidi

\footnotetext{
${ }^{26}$ Laporan Yasanti Program MAMPU

2017, Tanggal Proyek 1 Juni 2016

${ }^{27}$ Laporan Yasanti Program MAMPU

2017, Tanggal Proyek 1 Juni 2016
} 
iuran bagi PPR yang telah memiliki kartu BPJS Ketenagakerjaan.

$$
\text { Pada tahun 2018, BPJS }
$$

Ketenagakerjaan telah memberikan 100 kartu BPJS non upah bagi 100 orang perempuan pekerja rumahan dan keluarga, serta jaringan pekerja rumahan. ${ }^{28}$ Seperti yang diberikan kepada Kreatif Bunda (ada sembilan orang terdiri dari lima PPR dan empat Suami PPR), Bunda Mandiri (ada enam orang terdiri dari tiga PPR dan tiga suami PPR), Bunda Berkarya (ada tiga orang PPR), Ngudi Makmur (ada tiga orang terdiri dari dua PPR dan satu suami PPR), Kasih Bunda (ada lima orang terdiri dari empat PPR dan satu suami PPR), Sekar Melati (ada sepuluh orang PPR), Mutiara Bunda (ada empat belas orang terdiri dari delapan PPR dan enam suami PPR), Bunda Mulia (ada sebelas orang terdiri dari sembilan PPR dan dua suami PPR), Bunda Merdeka (ada enam orang PPR), Harapan Bunda (ada dua orang PPR). Pemberian kartu BPJS non upah ini merupakan hasil dari audiensi MAMPU terhadap BPJS Ketenagakerjaan.

\section{Memperbaiki Kondisi Perempuan Pekerja Rumahan dan Menghapuskan Diskriminasi di Tempat Kerja.}

Selain rentan mengalami kemiskinan pekerja rumahan rentan mengalami diskriminasi kerja karena tidak memiliki alur distribusi yang jelas. Kondisi ini mengakibatkan perlu adanya perbaikan kondisi kerja lebih lanjut bagi perempuan pekerja rumahan, yaitu ${ }^{29}$ :

1. Masalah kontrak tertulis bagi pekerja. Seperti yang telah dijelaskan sebelumnya bahwa pekerja rumahan

\footnotetext{
${ }^{28}$ Laporan Yasanti Catur Wulan Program MAMPU Juli-September 2018, Tanggal Proyek 1 Juni 2016

${ }^{29}$ ILO, Hak-Hak Dasar Pekerja Rumahan, https://www.ilo.org/wcmsp5/groups/public /@asia/@ro-bangkok/@ilojakarta/documents/publication/wcms_3180 $\underline{38 . p d f}$ diakses pada 22 Oktober 2018
}

tidak memiliki kontrak yang jelas dengan pemberi kerja, sehingga dari segi hukum dinilai masih sangat kurang dari kondisi layak sebagai pekerja informal. Dengan tidak adanya kontrak maka, kurang pengawasan dari pemerintah, hukum, pemberi kerja dan sesama pekerja rumahan. Mitra MAMPU membantu para pekerja rumahan agar mendapatkan kontrak kerja yang layak sesuai regulasi Undang-Undang No. 13 Tahun 2003 mengenai Ketenagakerjaan, sehingga para pekerja rumahan mendapatkan hak yang sama dengan pekerja di sektor informal lainnya.

2. Hubungan kerja antara pekerja perantara - pengusaha. Alur kerja yang sangat rumit menjadikan pekerja rumahan sulit terdeteksi keberadaannya, ${ }^{30}$ sehingga perlu adanya pencatatan jumlah pekerja rumahan yang bekerja di setiap perusahaan dan sub-kontrak yang mempekerjakan pekerja rumahan. Mitra MAMPU berkontribusi dalam pencatatan pekerja dan apabila memungkinkan mencatat pengusaha atau pemberi kerja, sehingga alur kerja yang selama ini rumit bagi pekerja rumahan menjadi lebih mudah dipahami, baik bagi pemerintah, pemberi kerja ataupun bagi pekerja rumahan itu sendiri.

3. Kebebasan berserikat. Setelah adanya pencatatan pekerja rumahan memiliki hak dalam berserikat, mitra MAMPU mendampingi pekerja rumahan dalam pembentukan serikat dan pengorganisasian ditiap-tiap kelompok di desa-desa

${ }^{30}$ Asosiasi Pengusaha Indonesia (APINDO), 2013, Panduan Praktik yang Baik untuk Mempekerjakan Pekerja Rumahan bagi Pengusaha, Jakarta, ILO, Hal. 14 
kabupaten/kota. ${ }^{31}$ Dengan adanya serikat, para pekerja rumahan dimudahkan dalam layanan informasi dan dapat menyuarakan aspirasi dan kebutuhan mereka kepada pemerintah.

4. Pengembangan kreativitas dan pembelajaran. Untuk memberdayakan pekerja rumahan, mitra MAMPU membantu pekerja rumahan dengan diadakannya sekolah Perempuan Pekerja Rumahan (PPR) sebagai wadah pembelajaran bagi pekerja rumahan dalam melakukan negosiasi kepada pemberi kerja, mengusulkan advokasi kepada pemerintah atau instansi terkait, mengatur organisasi yang telah terbentuk sehingga organisasi Serikat Perempuan Pekerja Rumahan (SPPR) menjadi maju dan berdaya, dan pembelajaran lain seperti peningkatan kualitas dan Sumber Daya Manusia (SDM) perempuan pekerja rumahan, memberikan pengenalan mendalam mengenai isu gender, dan belajar untuk berbicara di depan umum sebagai bekal pelatihan kepemimpinan.

$\begin{array}{ccc}\text { Untuk } & \text { lebih } & \begin{array}{c}\text { memperdalam } \\ \text { bagaimana }\end{array} \\ \text { MAMPU } & \text { memikan }\end{array}$ kesadaran kepada perempuan pekerja rumahan khususnya di Yogyakarta dalam memperbaiki kondisi kerja perempuan pekerja rumahan dan menghapuskan diskriminasi di tempat kerja, yaitu dengan cara: (1) Menyusun naskah akademik dan buku praktik baik, (2) membentuk serikat perempuan pekerja, (3) mendampingi pelatihan dan sekolah PPR dan (4) meningkatkan layanan informasi bagi pekerja.

\footnotetext{
${ }^{31}$ MAMPU, Perempuan Pekerja Rumahan di Bantul Bentuk Federasi Serikat Pekerja, http://mampu.or.id/ceritaperubahan/foto/perempuan-pekerjarumahan-di-bantul-deklarasikanpembentukan-federasi-serikat-pekerja/. Di akses pada 22 Oktober 2018
}

Biro Kesejahteraan Rakyat DIY / Biro Kesra DIY telah menyusun Naskah Akademik sebagai draff kebijakan perlindungan pekerja rumahan di Daerah Istimewa Yogyakarta dengan menggunakan dokumen analisis data 1.297 orang PPR DIY. ${ }^{32}$ Draff Naskah Akademik tersebut berisi kajian dari berbagai ahli di bidang hukum, sosiologi, ekonomi dan Badan Perencanaan Pembangunan Daerah (Bappeda) DIY. Dokumen hasil analisis data akan dijadikan bahan kajian untuk menyusun lembar kebijakan draff Naskah Akademik rancangan pemerintah daerah perlindungan pekerja rumahan DIY yang akan diusulkan ke DPRD DIY. Dokumen Draff Naskah Akademik Perlindungan Pekerja Rumahan DIY tersebut akan diserahkan ke DPRD DIY (Komisi C) agar dapat diproses pengadvokasiannya.

Selain menyusun Naskah Akademik mitra MAMPU menulis buku praktik baik. Buku praktik baik ini disusun dengan dua versi penyusunan, yaitu: yang pertama buku praktik baik yang berjudul "Panduan Praktik yang Baik untuk Mempekerjakan Pekerja Rumahan bagi Pengusaha" yang ditulis oleh Asosiasi Pengusaha Indonesia (Apindo) yang didukung oleh Australian Government dan International Labour Organization. ${ }^{33}$ Buku praktik baik ini telah diakses secara luas sejak tahun 2013 dan dapat diakses pada halaman website MAMPU yakni, mampu.or.id/category/publikasi. MAMPU melakukan publikasi terhadap buku praktik baik tersebut dengan harapan pengusaha ataupun pemberi kerja yang mempekerjakan perempuan pekerja rumahan dapat ikut serta dalam melakukan

\footnotetext{
${ }^{32}$ Draff Naskah Akademik dai Biro

Ketenagakerjaan DIY tahun 2018

${ }^{33}$ Asosiasi Pengusaha Indonesia

(APINDO), 2013, Panduan Praktik yang

Baik untuk Mempekerjakan Pekerja

Rumahan bagi Pengusaha, Jakarta, ILO,

Hal. 13-24
} 
pemberdayaan kepada para ibu rumah tangga yang bekerja sebagai pekerja rumahan.

Di dalam buku praktik baik tersebut terdapat cara-cara bertanggung jawab dalam mempekerjakan pekerja rumahan dengan adanya daftar pekerja rumahan yang dipekerjakan, adanya kontrak tertulis, cara yang baik apabila menggunakan perantara, memberikan pekerjaan yang teratur, menghilangkan perlakuan kasar apabila hal tersebut terjadi, penghapusan perlakuan nondiskriminasi terhadap pekerja, memberikan kebebasan berserikat dan kesepakatan kerja bersama, cara pengupahan yang sesuai dengan regulasi Undang-Undang, mengatur tenggat dan target produksi, memberikan pembayaran apabila pekerja rumahan membutuhkan cuti, mengatur usia minimum pekerja rumahan, bertanggung jawab dalam memberikan keringanan jaminan sosial serta memperhatikan Kesehatan dan Keselamatan Kerja (K3) bagi pekerja rumahan.

Buku praktik baik kedua yang berjudul "Pengakuan Negara Terhadap Serikat Perempuan Pekerja Rumahan (SPPR) secara tertulis 'Surat Keputusan Pengakuan dan Bukti Pencatatan SPPR", yang ditulis oleh Hikmah Diniah, Tri Wahyu dan Martini sebagai tim dari Yasanti. Buku praktik baik ini di rancang oleh mitra MAMPU yaitu Yasanti yang rencananya akan diperkenalkan pada Januari 2019, dengan tujuan adalah sebagai dokumentasi praktik baik dari program yang telah dilakukan MAMPU yaitu kebijakan pengakuan dan perlindungan bagi perempuan pekerja rumahan yang berupa Surat Keputusan (SK) pengakuan dan pencatatan dari pemerintah desa atau kelurahan dan surat bukti pencatatan dari Disnakertrans Kabupaten Bantul. ${ }^{34}$ Pengakuan yang telah

${ }^{34}$ Hikmah Diniyah, dkk, 2018, draff
Pengakuan Negara Terhadap Serikat diberikan dalam bentuk SK ini dapat menjadi payung hukum bagi perempuan pekerja rumahan dalam melakukan advokasi perlindungan hak atas kerja layak dan mengakses program perlindungan jaminan sosial, kesehatan dan ketenagakerjaan di DIY.

Untuk memperkuat dalam berbagai layanan dan kapasitas Perempuan Pekerja Rumahan, MAMPU membantu PPR untuk membentuk organisasi arau serikat di desa dan kelurahan di kabupaten dan kota di Daerah Istimewa Yogyakarta. Pembentukan serikat PPR ini bertujuan untuk memudahkan akses perlindungan bagi PPR dan menghindarkan PPR dalam segala macam bentuk diskriminasi kerja. Dengan adanya Serikat kerja atau organisasi PPR, pekerja rumahan dapat menyuarakan pendapatnya dan terhindar dari pekerjaan yang menumpuk atau pekerjaan yang tidak diberikan dalam waktu yang lama. Dengan adanya Serikat PPR memudahkan pekerja rumahan dalam mengakses informasi sehingga para pekerja rumahan mendapatkan informasi yang sama dari satu PPR dengan PPR lain.

Setelah melalui proses yang panjang dalam pembentukan organisasi PPR di Daerah Istimewa Yogyakarta muncul Organisasi atau serikat PPR di sepuluh desa/kelurahan atau kota/kabupaten di Yogyakarta. ${ }^{35}$ Yaitu: SPPR Kreatif Bunda Wonolelo per Juli 2018 anggota 78 orang, SPPR Bunda Mandiri Bawuran, per Juli 2018 jumlah anggota 33 orang, SPPR Bunda Berkarya Segoroyoso, per Juli 2018 jumlah anggota 36 orang, SPPR Ngudi Makmur Wukirsari, per juli 2018 jumlah anggota 27 orang, SPPR Kasih Bunda Bangujiwo, per april 2018 jumlah anggota

Perempuan Pekerja Rumahan (SPPR)

Secara Tertulis "SK Pengakuan dan Bukti Pencatatan SPPR” Hal. 6

${ }^{35}$ Laporan Yasanti Catur Wulan Program MAMPU Juli-September 2018, Tanggal Proyek 1 Juni 2016 
23 orang, SPPR Mutiara Bunda Prenggan Kota Gede, per juli 2018 jumlah anggota 15 orang, SPPR Bunda Mulia Tahunan Umbulharjo, per juli 2018 jumlah anggota 16 orang, SPPR Bunda Merdeka Tegal Panggung, Danurejan, per juli 2018, jumlah anggota 30 orang, SPPR Sekar Melati Cokrodiningratan Jetis, per juli 2018 jumlah anggota 22 orang, SPPR Harapan Bunda Notoprajan Ngampilan, per juli 2018 jumlah anggota 17 orang.

Perempuan Pekerja Rumahan di Yogyakarta juga mengalami peningkatan pengembangan disetiap tahunnya. Sejak tahun 2016-2018, PPR di Yogakarta terus menyuarakan aspirasinya sehingga kebutuhannya satu persatu mulai terpenuhi. Melalui sekolah PPR yang diadakan setiap bulan, PPR terus mengalami perubahan dan mereka semakin berani menyuarakan pendapatnya di depan pemerintah desa maupun pemerintah provinsi. ${ }^{36}$ Karena kebutuhan untuk mendapatkan informasi secara terbuka mengenai advokasi, negosiasi, pengorganisasian, kesadaran hukum, kepemimpinan, gender, $\mathrm{K} 3$ dan pendidikan keuangan, PPR secara aktif mengaplikasikan pembelajaran yang mereka dapat kedalam kepentingan mereka ketika ada pertemuan PPR dengan pemerintahan desa, kabupaten-kota ataupun provinsi.

Dari hasil belajar di sekolah PPR, mereka dapat belajr bagaiamana cara bernegosiasi. hasil dari negosiasi tersebut biasanya mereka mendapatkan akses terhadap pelatihan-pelatihan seperti pelatihan ketrampilan kerajinan tangan, pembuatan sablon, memasak, menjahit, dan ketrampilan lainnya yang dapat meningkatkan kualitas diri PPR. Mitra Yasanti sebagai perwakilan dari MAMPU melakukan pendampingan secara berkala terhadap para perempuan pekerja rumahan

\footnotetext{
${ }^{36}$ Laporan Yasanti Catur Wulan Program MAMPU Oktober - Desember 2016, Tanggal Proyek 1 Juni 2016
}

tersebut seperti pendampingan terhadap: usulan program pelatihan sablon dan menjahit berkelanjutan untuk PPR yang diajukan oleh pengurus SPPR Kreatif Bunda di desa Wonolelo, usulan akses program menjahit ke pemerintah Desa Bawuran oleh pengurus SPPR Bunda Mandiri, usulan akses program pelatihan membuat kue, pelatihan batik, pelatihan sablon kain, dan pelatihan pengolahan sumber bahan makanan lokal yang diajukan oleh pemimpin PPR Kasih Bunda Bangunjiwo, serta usulan program pelatihan kue khas lokal yang diajukan oleh pemimpin SPPR Bunda Berkarya. ${ }^{37}$

Pekerja rumahan berhak atas layanan informasi mengenai UU Ketenagakerjaan dan keterlibatannya di dalam masyarakat. Di dalam UU No. 14 Tahun 2008 mengenai Keterbukaan Informasi Publik BAB III, Pasal 4 ayat (1) yang berisi tentang setiap orang berhak memperoleh informasi publik sesuai dengan ketentuan Undang-Undang, tak terkecuali pekerja rumahan. Mereka berhak mendapatkan informasi serta keterlibatan bagi serikat pekerja untuk aktif di dalam masyarakat. Program MAMPU membuka jalan bagi pekerja rumahan dalam mengakses informasi tersebut, sehingga para pekerja rumahan dapat aktif di dalam kegiatan masyarakat baik itu dilingkup desa, kota, provinsi ataupun nasional. Untuk meningkatkan layanan informasi bagi pekerja rumahan, MAMPU mendukung dengan cara: memberikan pelatihan kepada anggota serikat perempuan pekerja (sppr) agar dapat menerima layanan informasi pekerja, serta melibatkan anggota sppr dalam program-program pemerintah desa, kabupaten/kota dan provinsi.

\footnotetext{
${ }^{37}$ Laporan Yasanti Catur Wulan Program MAMPU 2016-2018, Tanggal Proyek 1 Juni 2016
} 


\section{KESIMPULAN DAN SARAN}

Sebelum adanya program MAMPU tidak ada satupun instansi pemerintah dan masyarakat yang peduli terhadap nasib pekerja rumahan yang pada kenyataannya mereka telah ada di lingkungan sekitar kita selama bertahun-tahun lamanya. Organisasi perburuhan Internasional atau ILO telah membuat konvensi ILO No. 177 tahun 1996 mengenai pekerja rumahan namun pemerintah Indonesia belum merativikasi Konvensi tersebut. Pekerja rumahan mendapatkan banyak masalah yang dihadapi dan rentan mengalami kemiskinan, Undang-Undang Ketenagakerjaan No. 13 tahun 2003 tidak dapat membantu banyak mengenai permasalahan pekerja rumahan dikarenakan UU tersebut diperuntukkan bagi pekerja di sektor formal, sedangkan pekerja rumahan tidak memenuhi standar tersebut karena alur kerja yang terlalu rumit dan tidak adanya kontrak tertulis yang dapat melindungi pekerja informal. Akibatnya adalah pemenuhan hak bagi pekerja informal tidak dapat terpenuhi dengan baik.

Setelah adanya program MAMPU perempuan pekerja rumahan semakin dikenal dikalangan instansi pemerintah dan masyarakat, para perempuan pekerja rumahan pun menjadi sadar akan hakhaknya sebagai pekerja dan memiliki kemampuan dan kemauan membangun serikat pekerja. Program-program yang ditawarkan MAMPU pun dapat diterima oleh pekerja rumahan dengan baik khususnya dalam program peningkatkan akses pekerja rumahan pada program perlindungan sosial dan pemerintah dan memperbaiki kondisi perempuan pekerja rumahan dan menghapuskan diskriminasi di tempat kerja. Dengan adanya akses bagi para pekerja dalam perlindungan sosial, para pekerja rumahan menjadi mengerti akan pentingnya advokasi dan jaminan perlindungan sosial. Dengan adanya kesadaran akan memperbaiki kondisi kerja agar tercapainya kerja layak, mereka menjadi paham pentingnya berorganisasi khususnya organisasi serikat pekerja.

Berdasarkan peran MAMPU ini, telah menguatkan tentang pentingnya Kemitraan dan peran aktor non negara dalam hal ini Yasanti, untuk meningkatkan kesadaran masyarakat dalam hal ini PPR, untuk memahami keberadaan, perannya serta hak-hak yang harus diterimanya dalam konteks hubungan pekerjaan. Oleh karenanya pada masa yang akan datang keterlibatan aktor-aktor atau para pihak yang berasal dari masyarakat harus menjadi program prioritas pemerintah dalam pembangunan melalui program kemitraan strategis dan konstruktif.

\section{DAFTAR PUSTAKA}

Asosiasi Pengusaha Indonesia (APINDO). 2013. Panduan Praktik yang Baik untuk Mempekerjakan Pekerja Rumahan bagi Pengusaha, Jakarta: ILO

Dwi Prastya, Dinar. "Pekerja rumahan Indonesia di bawah bayangan patriarki dan kapitalisme global". http://theconversation.com/pekerja-rumahan-indonesia-dibawah-bayangan-patriarki-dan-kapitalisme-global-88963 diakses 25 Januari 2019

Data MAMPU 2018. "Perbaikan Kondisi Kerja”. http://mampu.or.id/tema/perbaikankondisi-kerja/, diakses pada 12 Desember 2018 
Data BPS 2016. "Sektor apa yang paling banyak serap pekerja wanita". https://databoks.katadata.co.id/datapublishembed/105974/sektor-apa-yang-palingbanyak-serap-pekerja-wanita, diakses 20 September 2018

Diniyah, Hikmah, dkk, 2018, “draff Pengakuan Negara Terhadap Serikat Perempuan Pekerja Rumahan (SPPR) Secara Tertulis "SK Pengakuan dan Bukti Pencatatan SPPR"

Ernawati, Eci. "Pekerja Rumahan dari Perspektif Trade union Rights Centre (TURC)", https://www.academia.edu/7954902/Pekerja_Rumahan_Home_Workers, Diakses 15 Oktober 2018.

ILO, "Cakupan pekerja rumah tangga di dalam undang-undang kondisi kerja utama" https://www.ilo.org/wcmsp5/groups/public/@asia/@ro-bangkok/@ilojakarta/documents/publication/wcms_166264.pdf

ILO.

"Hak-Hak

Dasar

Pekerja

Rumahan”.

https://www.ilo.org/wcmsp5/groups/public/@asia/@ro-bangkok/@ilo-

jakarta/documents/publication/wcms_318038.pdf, diakses pada 22 Oktober 2018

Jamsos Indonesia, "Serikat Pekerja Menolak perbudakan Modern", http://archives.jamsosindonesia.com/cetak/printout/555. diakses 10 November 2018.

"Kenapa Sektor informal perlu perlindungan BPJS Ketenagakerjaan?", https://jurnal.pasarpolis.com/2018/01/15/perlindungan-bpjs-ketenagakerjaan-sektorinformal/, Diakses pada 15 Januari 2019

Kema Ama, Kornelis. "Pekerja Rumahan dan Buruh Butuh Layanan Kesehatan dari Pemerintah”. https://kompas.id/baca/nusantara/2018/12/05/pekerja-rumahan-danburuh-butuh-layanan-kesehatan-pemerintah/, diakses pada 6 Desember 2018

Keputusan Gubernur Daerah Istimewa Yogyakarta No.: 223 Tahun 2017 tentang penetapan Upah Minimum Kabupaten/Kota

Komalasari, Dewi. 2017. Tujuan Pembangunan Berkelanjutan (TPB), Semai Edisi 3

Laporan YASANTI. 2016. “Catur Wulan Program MAMPU Oktober - Desember 2016”, Tanggal Proyek 1 Juni 2016

Laporan YASANTI, Program MAMPU 2017, Tanggal Proyek 1 Juni 2016

MAMPU. 2018, “Kerangka Kerja Kesetaraan Gender dan Pemberdayaan perempuan”, Buletin MAMPU, Edisi Agustus 2018

MAMPU, "Perempuan Pekerja Rumahan di Bantul Bentuk Federasi Serikat Pekerja", http://mampu.or.id/cerita-perubahan/foto/perempuan-pekerja-rumahan-di-bantuldeklarasikan-pembentukan-federasi-serikat-pekerja/. Diakses pada 22 Oktober 2018 
"Mendorong Perda Perempuan Pekerja rumahan di Yogyakarta". https://spn.or.id/mendorong-perda-perempuan-pekerja-rumahan-di-yogyakarta/. diakses pada 15 Desember 2018

Sawitra Mustika , I Ketut. "Ini Derita Pekerja Rumahan di Bantul”, https://jogjapolitan.harianjogja.com/read/2018/05/02/510/913665/ini-deritapekerja-rumahan-di-bantul diakses pada 22 Oktober 2018

Sigit, Agus. "KBR Suarakan Perlindungan Pekerja Rumahan", https://krjogja.com/web/news/read/77976/KBR_Suarakan_Perlindungan_Pekerja_R umahan, Diakses pada 22 Oktober 2018

TURC, “Siapa Pekerja Rumahan?”, https://www.turc.or.id/siapa-pekerja-rumahan/, Diakses pada 13 Desember 2018

Wiharnato, Urip. 2018. "Pekerja Rumahan di DIY dan sistem out sourching”, Kumpulan Dokumen Hasil Seminar dengan Tema "Perburuhan" YASANTI 2016

YASANTI, "Lembar kebijakan: Pentingnya perlindungan dan pengakuan bagi pekerja rumahan DIY”. Diajukan ke DPRD pada tanggal 26 November 2018

Zuardin. 2016. "Petakan segera pekerja sektor informal", http://www.jamsosindonesia.com/opini/petakan_segera_pekerja_sektor_informal. Diakses pada 6 Januari 2019 